\title{
In vitro properties of chitosan nanoparticles induce apoptosis in human lymphoma SUDHL-4 cell line
}

\author{
Umesh K. Parida ${ }^{1}$, Niranjan Rout ${ }^{2}$, Birendra K. Bindhani ${ }^{{ }^{*}}$ \\ ${ }_{1}^{1}$ School of Biotechnology, KIIT University, Bhubaneswar, India \\ ${ }^{2}$ Acharya Harihar Regional Cancer Center, Cuttack, India \\ Email: drbindhani@gmail.com
}

Received 26 August 2013; revised 25 November 2013; accepted 7 December 2013

Copyright (C) 2013 Umesh K. Parida et al. This is an open access article distributed under the Creative Commons Attribution License, which permits unrestricted use, distribution, and reproduction in any medium, provided the original work is properly cited.

\begin{abstract}
In this study, the possible mechanisms were investigated with chitosan nanoparticles using sodium tripoly-phosphate and effects on human lymphoma SUDHL-4 in vitro. It was characterized by XRD, FTIR, TGA, particle Size, zeta potential, SEM \& TEM. Different techniques such as cell proliferation, ultra structure changes, DNA fragmentation, phase distribution of cell cycle, MTT assay, MMP, agarose gel electrophoresis of DNA, flow cytometry and electron microscopy were used with treatment of different concentrations of $\mathrm{CH}-\mathrm{NPs}(25,50,75,100 \mu \mathrm{g} / \mathrm{ml})$ at different time periods. Electron microscopy study revealed that the chitosan nanoparticles showed 78 $\mathbf{n m}$ particle size which is a high surface charge as $\mathbf{5 2}$ $\mathrm{mV}$. Inhibition of chitosan nanoparticles after $48 \mathrm{~h}$ treatment was marked in cell proliferation of SUDHL4 with an $\mathrm{IC}_{50}$ value of $5 \mu \mathrm{gg} / \mathrm{ml}$. Electron microscopy showed typical necrotic cell morphology after treatment of chitosan nanoparticles. The DNA degradation related with necrosis was determined using agarose electrophoresis and loss of MMP \& occurrence of apoptosis was analyzed by flow cytometry. Chitosan nanoparticles with low molecular weight (LMW) were comparatively stable in medium containing aqueous and rate of dissolution was slow in acidic medium. Results of this present study clearly provided information that the chitosan nanoparticles effectively inhibit the proliferation of SUDHL-4 through multiple mechanisms in vitro and this novel formulation can open a new avenue against human Lymphoma.
\end{abstract}

Keywords: Chitosan Nanoparticles; Sodium Triphosphate; SUDHL-4; Apoptosis; MTT Assay

${ }^{*}$ Corresponding author.

\section{INTRODUCTION}

Biomedical applications of chitosan include, drug delivery, tissue engineering, wound dressings, implant coatings and therapeutic agent delivery systems. Chitosans are biocompatible, profuse, nontoxic, biodegradable and renewable carbohydrate polymers [1-7].

Recent research has revealed the antimicrobial potential of chitosan on its $M_{r}$ and DA [8-12] and higher viscosity of $\mathrm{M}_{\mathrm{r}}$ and chitosan solutions have its multidimensional benefit. Alternatively, the low molecular weight chitosans could be depolymerised by physical, acidic or enzymatic methods. The highest bacterial activity towards pathogenic bacteria was found in LMWC $(5-10 \mathrm{kDa})$ [13], whereas, $20 \mathrm{kDa}$ product prevented progression of diabetes mellitus and showed a higher affinity for lipopolysaccharides (LPS) than the native chitosan $\sim 140 \mathrm{kDa}$ [14]. The sensible use of LMWC in milk safeguarding and oral hygiene is also reported [15].

It was reported that chitosan is biocompatibility and biodegradability $[16,17]$ applied in drug delivery systems to prepare encapsulation of drugs, enzymes, proteins and DNA in nanospheres or microspheres level [18-20]. Drugs for biological activities could be developed by using chitisan only. Both soluble and microspheres chitosan showed a type of toxic in murine melanoma cell line and chitosan with hydrochloride exhibited extra toxic with an $\mathrm{IC}_{50}$ [21]. Dose dependent inhibitory effects of amino cationic chitosan derivatives showed the proliferation of numerous tumour cell lines with lowest $\mathrm{IC}_{50}$ towards liver cancer [22,23].

The most important properties of CH-NPs could provide a high resemblance used for negatively charged biological membranes and targeting specific site in vivo [13]. The CH-NPs with different concentrations could inhibit the dissimilar proliferated tumour cell lines whereas it could be toxic against normal liver cells [19]. 
The present investigations illustrate the possible mechanisms of CH-NPs and effects on the proliferation of human Lymphoma, SUDHL-4 cell line. It was characterized using electron microscopy, MTT assay, agarose electrophoresis of DNA, and flow cytometry.

\section{MATERIALS AND METHODS}

Chitosan was obtained from himedia and sodium tripolyphosphate (TPP), $\mathrm{NaOH}$, acetic acid, $\mathrm{NaH}_{2} \mathrm{PO}_{4}$, were obtained from Hindustan scientific Linker, Odisha, India. SUDHL-4 (Cell Lines) was maintained in School of Biotechnology, KIIT University, Odisha, India. It was grown in medium (i.e., RPMI-1640) supplemented with $10 \%$ foetal calf serum in a humidified incubator at $37^{\circ} \mathrm{C}$ along with $5 \% \mathrm{CO}_{2}$. Collagen coated culture flasks were used when necessary and water was always used in demineralised form.

\subsection{Isolation of LMWC}

Different concentration of chitosan solution was treated with pronase in the ratio 100:1 (w/w), incubated for different periods at $37^{\circ} \mathrm{C}$ followed by arresting the reaction by heat denaturing the enzyme $\left(100^{\circ} \mathrm{C}\right)$ and added equal volume of $2 \mathrm{~N} \mathrm{NaOH}$. The precipitated LMWC was obtained after centrifugation (3000 rpm, $10 \mathrm{~min})$. Then, it was dialyzed against deionised water using a membrane and freeze dried.

\subsection{Preparation of Nanoparticles}

There are three different types of chitosan such as $6 \mathrm{kDa}$, $8 \mathrm{kDa}$ and $10 \mathrm{kDa}$. The chitosan with $6 \mathrm{kDa}$ was used more preferably as it is more compressed then the chitosan $8 \mathrm{kDa}$ and $10 \mathrm{kDa}$. Chitosan nanoparticles (CHNPs) were synthesized via the ionotropic gelation [5] of chitosan with TPP anions. The synthesis of different concentrations of CH-NPs was first optimized and then dissolved in acetic acid (1\%). The sodium tripolyphosphate (TPP) solution $(1 \mathrm{mg} / \mathrm{ml})$ was prepared by double distilled water. Chitosan nanoparticles were spontaneously fabricated with the drop wise addition of TPP solution $(\mathrm{CH} / \mathrm{TPP}=4: 1)$ under magnetic stirring $(1000 \mathrm{rpm})$ at room temperature (Figure 1(a)).

The opalescent suspension was shaped under the similar above mentioned conditions. The nanoparticles were separated by centrifugation at $20,000 \mathrm{~g}$ and $14^{\circ} \mathrm{C}$ for 30 minutes and supernatants was discarded, freezedried and stored at $5^{\circ} \mathrm{C} \pm 3^{\circ} \mathrm{C}$. The weight of freeze-dried nanoparticles was calculated.

\subsection{Characterization}

\subsubsection{LMW Chitosan}

Three dissimilar LMW chitosan were prepared on the

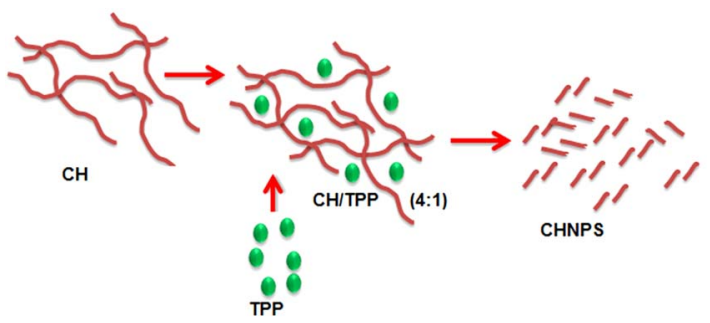

(a)

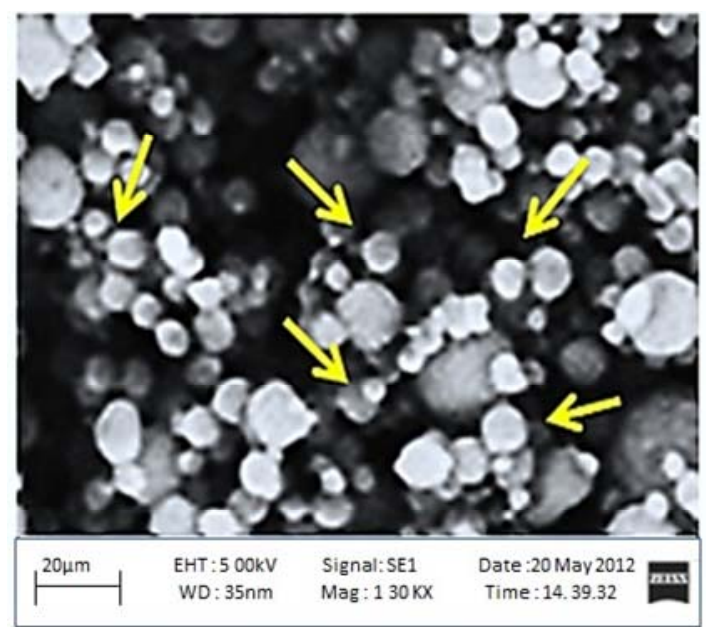

(b)

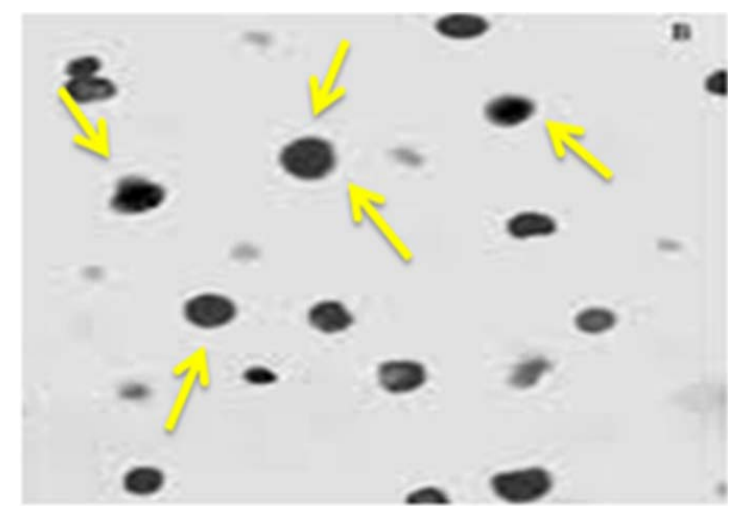

(c)

Figure 1. (a) A schematic design for preparation of the chitosan nanoparticles using sodium tripolyphosphate (TPP); (b) Scanning electron microscopy of chitosan nanoparticles; (c) Transmission electron microscopy of chitosan nanoparticles.

basis of $\mathrm{H}$ NMR technique and viscosity method respectively. The $\mathrm{M}_{\mathrm{r}}$ of chitosan used in this study was 6,8 and $10 \mathrm{kDa}$. All chitosan grades were found to be entirely deacetylated.

\subsubsection{SEM (Scanning Electron Microscopy) Analysis} To observe the morphological features, Field Emission Scanning Electron Microscopy, JEOL, JSM-6700F, Japan was used. By using sputter coated with a $5 \mathrm{~nm}$ thick gold, the samples were sprinkled. 


\subsubsection{TEM (Transmission Electron Microscopy) Analysis}

TEM analysis was performed on a Hitachi H-8100 electron microscope with an acceleration voltage of $200 \mathrm{kV}$.

\subsubsection{XRD (X-Ray Diffraction) Analysis}

It was carried out using BEDE D-3 system with $\mathrm{Cu} \mathrm{K} \alpha$ radiation at a generator or voltage of $40 \mathrm{kV}$ and a generator current of $100 \mathrm{~mA}$. The samples were scanned from scanned from $2 \theta=1-100^{\circ}$ at a scanning rate of $2 \%$ min.

\subsubsection{Zeta Size and Potential Analysis}

A Malvern Instrument, MAL 1037088, USA was used to determine the standard size of particle and zeta potential of nanoparticles. Disposable zeta cells measurement was carried with ultra pure water at $25^{\circ} \mathrm{C}$ with a $-50 \mathrm{mV}$ latex standard calibrated frequently. The mean zeta potential was carried out using phase analysis light scattering technique.

\subsubsection{FT-IR Analysis}

A Perkin-Elmer Model of FTIR spectrophotometer, USA within the range of $4000-400 \mathrm{~cm}^{-1}$ was used for the samples analysis. Approximately, sample of $5 \mathrm{mg}$ was with $\mathrm{KBr}(100 \mathrm{mg})$ and condensed into pellet using hydraulic press. The $\mathrm{KBr}$ pellet methods were used for all FT-IR spectra analysis.

\subsubsection{Thermo Gravimetric Analysis (TGA)}

Thermo gravimetric analysis (Perkin Elmer Model, USA) was used having unit of microprocessor temperature control with TA data station. The samples mass generally in the range of 2 - $3 \mathrm{mg}$ was used. An equipment consist of both sample pan with balance system was placed in temperature ranges from $25^{\circ} \mathrm{C}$ to $800^{\circ} \mathrm{C}$ with $50 \mathrm{~cm}^{3} / \mathrm{min}$. flow rate of nitrogen. The mass of sample pan was recorded constantly as a function of temperature.

\subsubsection{Cell Viability Assay}

In this case, cell (SUDHL-4) suspension with $100 \mu \mathrm{l}$ aliquot containing $10^{6}$ cells was added to every well of a 96 well plate (Corning, USA) and cultured $24 \mathrm{~h}$. Then cells were treated immediately with different concentrations of CH-NPs such as $25 \mu \mathrm{g} / \mathrm{ml}, 50 \mu \mathrm{g} / \mathrm{ml}, 75 \mu \mathrm{g} / \mathrm{ml}$ and $100 \mu \mathrm{g} / \mathrm{ml}$ for another 24 or $48 \mathrm{~h}$. The tetrazolium dye assay was used to know the consequence of diverse treatments on cell viability. The data in this study were expressed as mean $\pm \mathrm{SD}$.

\subsubsection{DNA Fragmentation}

First cells were treated with $100 \mu \mathrm{g} / \mathrm{ml} \mathrm{CH-NPs} \mathrm{for} 6$ or $24 \mathrm{~h}$, and then collected cells were washed using PBS followed by lyses. Then, such cells were used for extraction of DNA with phenol/chloroform/isoamyl alcohol (25:24:1) followed by chloroform. Precipitation of DNA was observed with two volumes of ethanol followed by $0.3 \mathrm{~mol} / \mathrm{l}$ sodium acetate. Finally, DNA samples were obtained and visualized by agarose gel electrophoresis.

\subsubsection{Determination of Mitochondrial Membrane Potential (MMP)}

In this study, SUDHL-4 cells were treated with different concentrations $(25 \mu \mathrm{g} / \mathrm{ml}, 50 \mu \mathrm{g} / \mathrm{ml}, 75 \mu \mathrm{g} / \mathrm{ml}$ and 100 $\mu \mathrm{g} / \mathrm{ml}$ ) of CH-NPs and followed by staining using rhodamine $123(10 \mu \mathrm{g} / \mathrm{ml})$ which is simply sequestered by MMP [13]. The rhodamine 123 was washed of the cells after loss of MMP. The mitochondrial membrane potential was find out using FACS calibur flow cytometer. For MMP analysis, the Cell Quest software program (BD Phar Mingen, Franklin Lakes, USA) was used.

\subsubsection{Cell Cycle Analysis}

Determination of DNA content and peaks of the apoptotic cells was done using flow cytometry. SUDHL-4 cells were grown in RPMI-1640 supplemented with $10 \%$ FBS. Different concentrations $(25 \mu \mathrm{g} / \mathrm{ml}, 50 \mu \mathrm{g} / \mathrm{ml}, 75$ $\mu \mathrm{g} / \mathrm{ml}$ and $100 \mu \mathrm{g} / \mathrm{ml}$ ) of CH-NPs were treated for $24 \mathrm{~h}$, after treatments cells were collected and stored at $4{ }^{\circ} \mathrm{C}$. Fixation cells were washed, centrifuged and re-suspended in propidium iodine $(0.05 \mathrm{mg} / \mathrm{ml})$, RNase $(100 \mathrm{U} / \mathrm{ml})$ in PBS. The sample was incubated and analysed by Calibur flow Cytometer. The Cell Quest software and MOdFit software was used to determine the cell cycle data. In this study the negative controls were also maintained against the positive controls.

\section{RESULTS AND DISCUSSIONS}

\subsection{Determination of LMWC}

The determination of $\mathrm{M}_{\mathrm{r}}$ (i.e., $71 \pm 2 \mathrm{kDa}$ ) of native chitosan was done using GPC on Sepharose CL-4B and calculated its value in accordance with viscometry. In good agreement with each other, the DA was calculated from IR and ${ }^{1} \mathrm{H}-\mathrm{NMR}$ data. Different molecular weight (i.e., 10.5 and $6.5 \mathrm{kDa}$ ) values were calculated in different time intervals (i.e., $2-8 \mathrm{~h}$ ) by HPLC and GPC. LMWC of free- $\mathrm{NH}_{2}$ groups and the column material showed minimum interaction using acetate buffer. The preparations of LMWC showed indicative molecular homogeneity with single symmetrical peak (Table 1) [2428].

\subsection{Scanning Electron Microscopy and Transmission Electron Microscopy Analysis}

The bare chitosan nanoparticle (CH-NP) with size 
Table 1. Characteristics and percent yield of LMWC.

\begin{tabular}{|c|c|c|c|c|}
\hline \multirow{2}{*}{ Chitosan } & \multirow{2}{*}{$\mathrm{Mr}(\mathrm{kDa})$} & \multicolumn{2}{|c|}{ DA (\%) } & \multirow{2}{*}{ Yield \% } \\
\hline & & IR & H-NMR & \\
\hline Native & $71.0 \pm 2.0^{\mathrm{a}}$ & 26.78 & 24.53 & - \\
\hline LMWC $-2 \mathrm{~h}$ & $10.50 \pm 0.15^{\mathrm{b}}$ & 18.04 & 17.87 & 82 \\
\hline LMWC $-4 \mathrm{~h}$ & $8.10 \pm 0.12^{\mathrm{b}}$ & 15.34 & 15.08 & 78 \\
\hline LMWC $-8 \mathrm{~h}$ & $6.50 \pm 0.12^{\mathrm{b}}$ & 13.29 & 13.34 & 76 \\
\hline
\end{tabular}

${ }^{\mathrm{a}}$ Determined by GPC on sepharose CL-4B column; ${ }^{\mathrm{b}}$ Determined by HPLC.

magnifications was done by SEM analysis (Figure 1(b)). The morphology of bare chitosan nanoparticle was shown about $78 \mathrm{~nm}$ in diameter with spherical in shape and found to be agreement. The particle size was decreased due to its aggregation and high specific surface energy [29].

In TEM analysis, chitosan nanoparticles exhibited round shaped due to vesicle disruption (Figure 1(c)) [30].

\subsection{Stability and Biocompatible of the Nanoparticles}

The biocompatibility nanoparticles with storage ability are great concern in pharmaceuitical fields. It is known that small size particles are inclined to agglomerate due to reduce free surface area and energy. Different concentrations of TPP were prepared with 2 - 90 days storage time at $4^{\circ} \mathrm{C}$ to determine the size of nanoparticles (Figure 2(a)). Each and every particle was stable with neglectable fluctuated size within 15 days and some particles were shown larger in size at 90 days. The best storage stability was observed in different concentration of TPP $(1.0-1.25 \mathrm{mg} / \mathrm{ml}$ at $\mathrm{pH} 6.0)$. The nanoparticles were precipitated continuously in undisturbed condition for some days and re-dispersed easily by moderate shaking.

At higher concentrations of TPP, the chitosan nanoparticles showed higher degree of cross linking whereas it is acceptable in decrease concentration of chitosan. Thus, it is resulted more compact particle structure. At the same time, particles showed smaller net charge due to neutralization of amino groups. It was also observed that smaller size particles structure due to compact and weakened charge repulsion in higher concentration of TPP.

\subsection{XRD Analysis}

In XRD analysis both pure and cross linked chitosans have been studied in the $2 \theta$ range of $5^{\circ}$ to $60^{\circ}$. The XRD profile of chitosan shows peaks at $23^{\circ}$ and $50^{\circ} 2 \theta$ (Figure 2(b)). The crystallinity of the chitosan $(3.02 \%)$ in

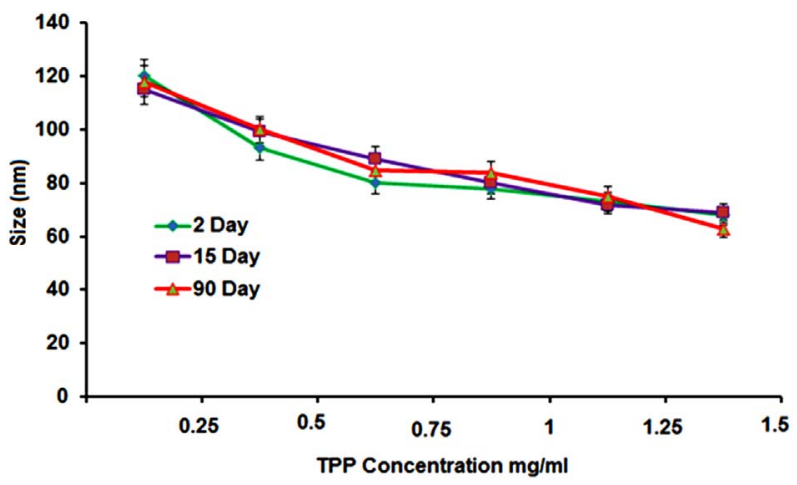

(a)

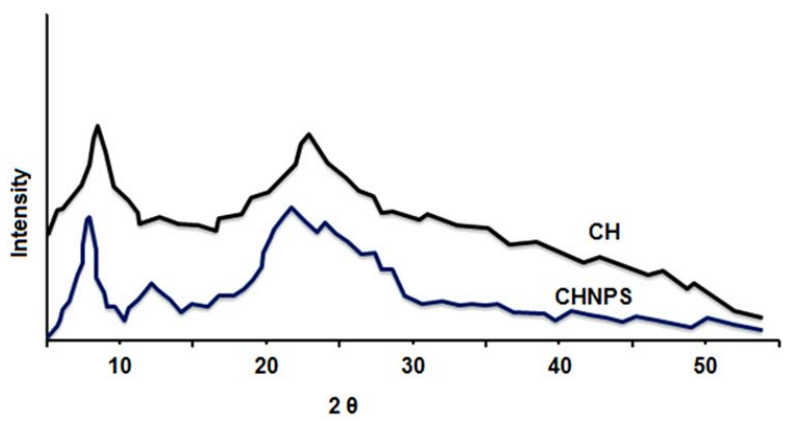

(b)

Figure 2. (a) Alteration of average size of chitosan nanoparticles with different TPP concentration during a storage time of 2 - 90 days at $4^{\circ} \mathrm{C}$; (b) XRD patterns of chitosan and developed membranes.

creases with the increase in degree of deacetylation and is attributed to enlarge in intermolecular hydrogen bonding due to the occurrence of more free $\mathrm{NH}_{2}$ groups (Higher Degree of Deacetylation) within the molecular structure, which in turn results the better packing of the macromolecular polymeric chains and consequent increase in the crystallinity.

\subsection{Surface Morphology of SUDHL-4}

The distraction of nuclear and cellular membrane exhibited necrosis under acute physiological stimuli condition. This important cause has been used to make a distinction necrosis from apoptosis of cellular membrane [31]. The chitosan nanoparticles treated with SUDHL-4 cells showed an ultra structure under SEM and TEM. Distinctive morphological characteristics of necrosis were observed in SUDHL-4 cells after treatment of chitosan nanoparticles. The SEM analysis showed both surface morphology and normal shape in control SUDHL-4 cells but large numbers of irregular microvilli were found in cell surface. After 30 minutes treatment of chitosan nanoparticles, cell death was induced due to leakage of early membrane and reduction of microvilli. After $2 \mathrm{~h}$ treatment of chitosan nanoparticles showed disintegration of microvilli and asymmetrical tiny holes with frac- 
turing membrane solubilisation. The SUDHL-4 cells thus, damaged extensively and looked like as honeycomb shape after $4 \mathrm{~h}$ treatment. This type of necrotic cell death was observed due to pore forming surface morphology as well as loss of membrane integrity after the interface of CH-NP and plasma membrane. In TEM analysis, disruptions of cytoplasm and enlargement of organelles were observed in chitosan nanoparticles treated with necrotic SUDHL-4 cells whereas disrupted microvilli along with normal organelles in untreated cells. But vacuolated cells and complete disruption of plasma membrane were mainly observed after $24 \mathrm{~h}$ treatment with chitosan nanoparticles [32] (Figures 3(A)-(D)).

\subsection{Zeta Size and Potential of Chitosan Nanoparticles}

The normal chitosan nanoparticle size was $65 \mathrm{~nm}$ and average distribution size ranges starting 46 to $83 \mathrm{~nm}$ (Figure 4). In zeta potential, the stability of particle was significantly inclined on surface charge during the electrostatic repulsion among the particles. Our scanning electron microscopy studies of chitosan nanoparticles were almost coincide with the average particle size of chitosan nanoparticles (CH-NP). Measurement of zeta potential was one of the major indexes to determine the stability of nanoparticle suspension. Nanoparticles with
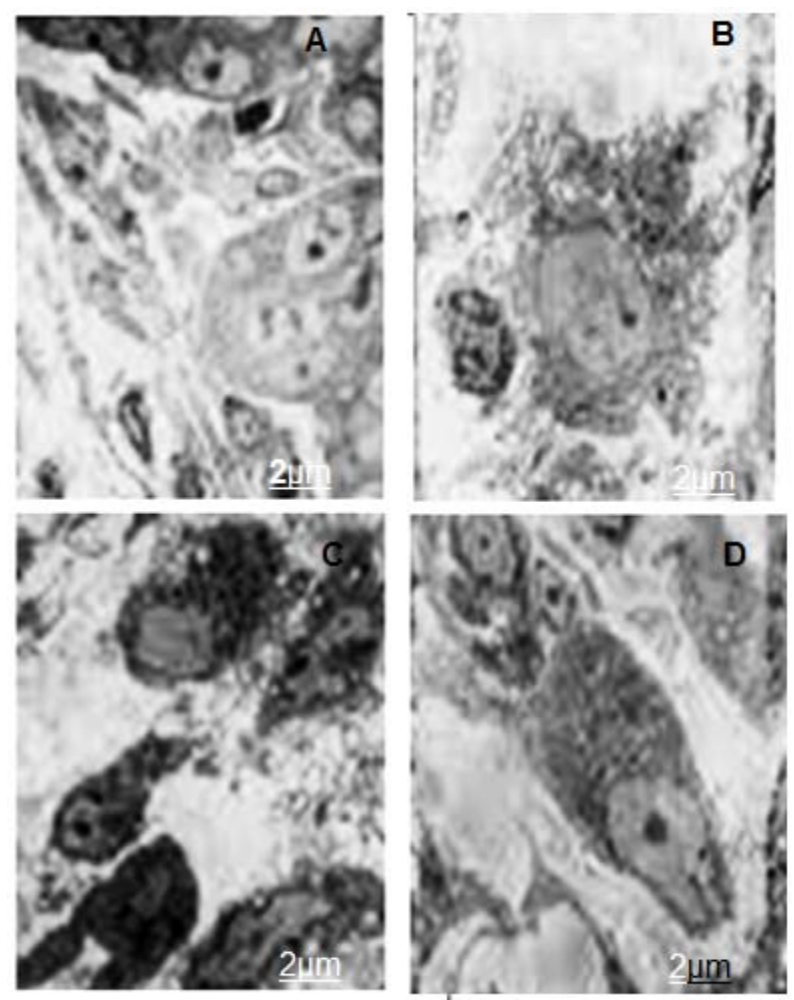

Figure 3. (A) Surface morphology of SUDHL-4 cells treated with $100 \mu \mathrm{g} / \mathrm{mL}$ chitosan nanoparticles for control cells; (B) 30 $\min$; (C) $2 \mathrm{~h}$; and (D) $4 \mathrm{~h}$.

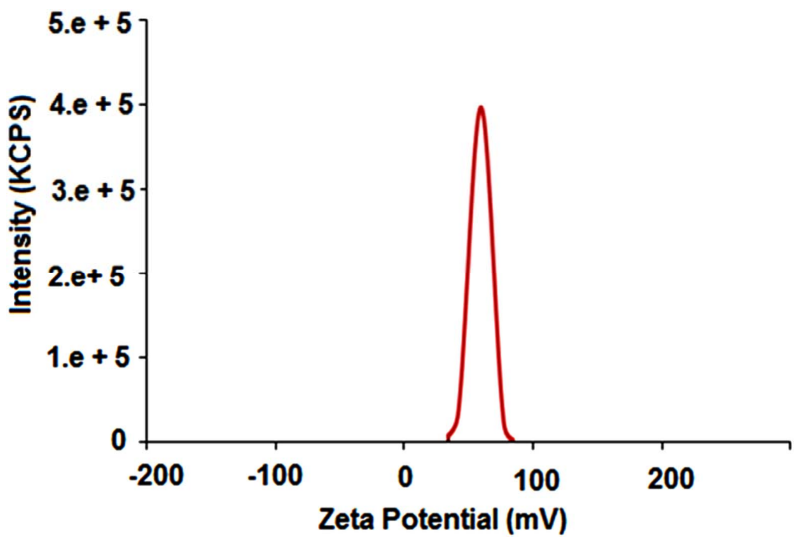

Figure 4. Size distributions of chitosan nanoparticles.

high electric surface charge showed high value of zeta potential due to repulsive forces between particles which leads to stop it from aggregation [33,34].

\subsection{FTIR Analysis}

In Figure 5(a), the transmission infrared spectra of powdered sodium tripolyphosphate (TPP), chitosan (CH) and ionically cross-linked chitosan/sodium tripolyphosphate (synthesized by cross-linking in TPP solution) are shown. A broad peak at $3433 \mathrm{~cm}^{-1}$ was shown in the bare $\mathrm{CH}^{-} \mathrm{NP}$ which corresponds to $\mathrm{NH}$ vibrational frequency. Generally, N-H stretching at $3500-3200 \mathrm{~nm}$ and N-H bend at $1550-1450 \mathrm{~nm}$ are observed in primary amino functional group. In FTIR spectrum, the region 4000 $2000 \mathrm{~nm}$ was excluded due to interference of water molecules. The FTIR of TPP has both symmetric stretching and also asymmetric bending at $1022 \mathrm{~nm}$ and at 615 $\mathrm{nm}$ respectively. In such region (i.e., $615 \mathrm{~nm}$ and 1022 $\mathrm{nm}$ ), two peaks were observed due to presence of phosphate in TPP chitosan $[35,36]$. It was also depicted the ionic bonding among the TPP and primary amine groups in TPP chitosan. Therefore, it implies that the occurrence of ammonium groups in TPP chitosan for such crosslinking reaction [37].

\subsection{TGA Analysis}

TGA analysis is normally used to determine the sample stability and loss of weight in diverse temperature. In this present study, TGA analysis of chitosan nanoparticles showed decomposition patterns in four stages (Figure 5(b)). In first stage, loss of weight (i.e., $6 \%$ ) at $175^{\circ} \mathrm{C}$ was observed because of the release of water molecules. In second stage, loss of weight (i.e., $22 \%$ approximately) at $365^{\circ} \mathrm{C}$ was observed due to chitosan decomposition. In third stage, the loss of weight (i.e., 19\%) was observed at $500^{\circ} \mathrm{C}$ caused by decomposition. At last, in fourth stage, such decomposition of chitosan was observed at $635^{\circ} \mathrm{C}$ with $16.79 \%$ of weight loss. However, the loss of weight 


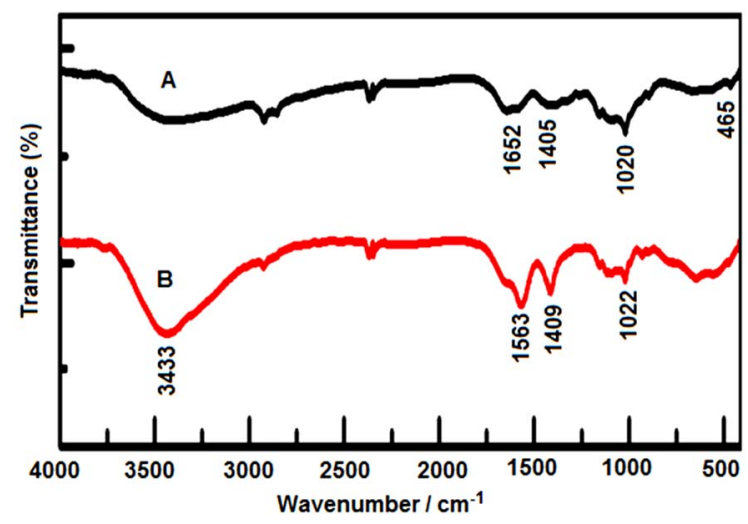

(a)

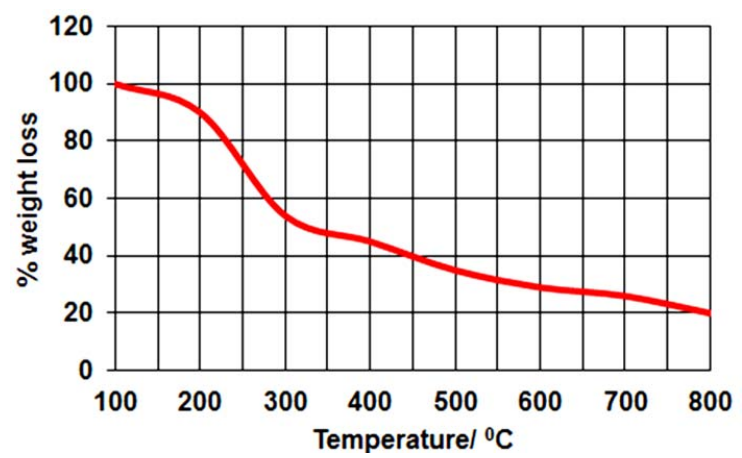

(b)

Figure 5. (a) FT-IR spectrum of CS, bare CS-NP; (b) Thermogravimetric analysis of CS-NP.

was also examined in two stages due to decomposition of chitosan within the range of $320^{\circ} \mathrm{C}$ and $470^{\circ} \mathrm{C}[38,39]$. Our result could correlate with this report.

\subsection{Cell Viability Assay}

The MTT cell viability assay of SUDHL- 4 cells treated using different concentrations of CH-NPs ranging as of 25 to $100 \mu \mathrm{g} / \mathrm{ml}$ were observed. The viability cells were inhibited by CH-NPs in varied dose and time. Chitosan nanoparticles in median lethal concentration were 15 and $5 \mu \mathrm{g} / \mathrm{ml}$ for SUDHL-4 cells at 24 and $48 \mathrm{~h}$, respectively (Figure 6). A high cytotoxicity against human lymphoma cell line could exert in chitosan nanoparticles. It was proved that the cell line is susceptible to CH-NPs by an $\mathrm{IC}_{50}$ value of $5 \mu \mathrm{g} / \mathrm{ml}$ after $48 \mathrm{~h}$ treatment and signifying that CH-NPs perhaps an excellent choice for antitumor drugs. Thus, size of the nanoparticles was mostly responsible in antitumor activity and in vivo distribution. Higher accumulation of tumour sites and makes longer half-life in vivo due to small size of nanoparticles [4043].

\subsection{DNA Fragmentation}

The cultured SUDHL-4 cells treated (i.e., 6 or $24 \mathrm{~h}$ ) with $100 \mu \mathrm{g} / \mathrm{ml} \mathrm{CH}-\mathrm{NPs}$ were used for DNA extraction and detected necrosis by agarose gel electrophoresis. The DNA derivative with necrotic degeneration [44] was found after $6 \mathrm{~h}$ of incubation whereas larger DNA fragmentation was detected after $24 \mathrm{~h}$ of treatment with chitosan nanoparticles (Figure 7).

A series of "DNA Ladders" was observed in fragmented DNA due to formation of oligonucleosomes in apoptosis $[45,46]$. The fragmented DNA appears spectrum of size permanently during necrosis in contrast [43]. Thus, present study indicated that CH-NPs treated with tumour cells are mainly responsible for necrosis in fragmented DNA continuously.

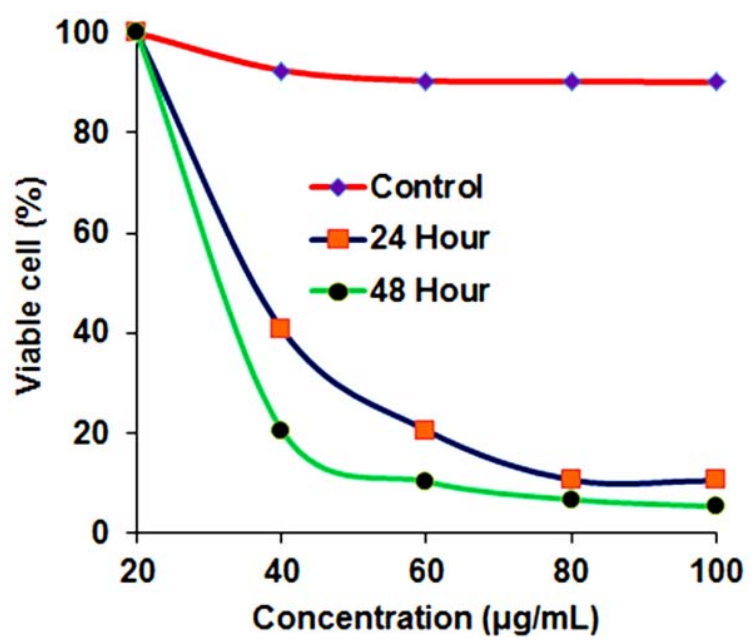

Figure 6. Inhibition of chitosan nanoparticles on SUDHL4 cell proliferation.

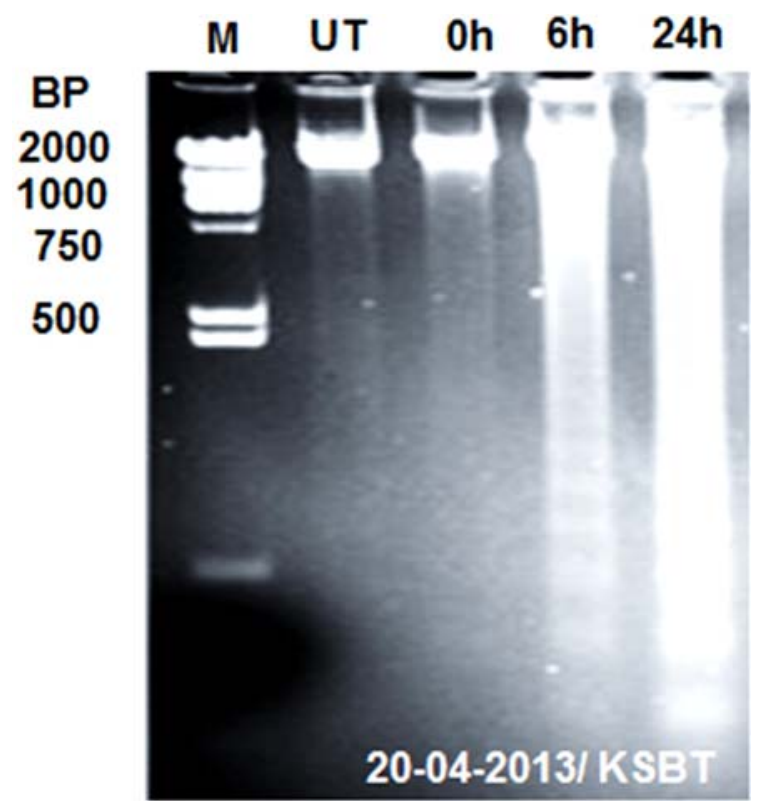

Figure 7. Showing agarose gel electrophoretic analysis of DNA isolated from SUDHL-4 cells incubated with 100 $\mu \mathrm{g} / \mathrm{mL}$ chitosan nanoparticles for $6 \mathrm{~h}$ (lane 2) and $24 \mathrm{~h}$ (lane 3) or without treatment (lane 1). M: a DNA marker. 


\subsection{Alternations of Mitochondial Membrane Potential (MMP)}

One of the promising mechanisms concerned for mitochondrial damage which is induced by CH-NPs in the necrosis of SUDHL-4 cells. In Present study, decrease mitochondrial membrane potential in SUDHL-4 cells was observed in different concentration of chitosan nanoparticles after $4 \mathrm{~h}$ of treatments. It was also observed that increased percentage of cells with loss of mitochondrial membrane potential extensively with more concentrations of CH-NPs. It was $74 \%$ with $100 \mu \mathrm{g} / \mathrm{ml}$ concentration of CH-NPs. The possible disruption of cell mitochondrial membrane and also strong disruption in mitochondrial membrane potential was observed after the treatment of chitosan nanoparticles (Figures 8(a) and (b)).

Regulation of cell death mainly takes place by mitochondria which were already reported [47]. In high $\mathrm{Ca}^{2+}$ and oxidative stress, mitochondria forced to changes which were swelling, de-energization, decrease mitochondrial potential and inner membrane permeabilization [48]. In addition, necrotic cell death and loss of integrity in plasma membrane were observed due to dysfunction of mitochondria [49]. In this investigation, CH-NPs treated with lymphoma cells showed extreme decline of mitochondria membrane potential which indicated that the mitochondrial membrane is damaged (Figure 8(c)).

\subsection{Effects of Cell Cycle}

Different effects of CH-NPs treated with SUDHL-4 cells on cell cycle were determined by flow cytometry. The effects of CH-NPs were identified and a comparison was made in both treated and untreated cells on cell cycle. This finding was confirmed in the $G_{0} / G_{1}$ phase of cell cycle and also observed significant decrease of cells. The CH-NPs treatment with dose dependent manner showed apoptotic peaks and cell apoptotic incidence $(9.9 \%$ in $100 \mu \mathrm{g} / \mathrm{ml}$ ) [50]. The apoptotic incidence was increase up to $10.23 \%$ after treatment with $100 \mu \mathrm{g} / \mathrm{ml}$ chitosan nanoparticles (CH-NPs) (Figures 9(a) and (b)). This analysis exhibited that different concentrations of CH-NPs has major role for cell death and significant decline of cells in $\mathrm{G}_{0} / \mathrm{G}_{1}$ phase. This study also stated that $\mathrm{CH}-\mathrm{NPs}$ showed high cytotoxicity towards lymphoma SUDHL-4 with necrotic cell death in about $52 \mathrm{mV}$ positive surface charge and about $78 \mathrm{~nm}$ particle size. The CH-NPs and its antitumor mechanism are correlated with membrane disorderly inducing apoptosis activities.

\section{CONCLUSION}

In this investigation, we have developed a new method for synthesis of CH-NPs using ionic gelation technique

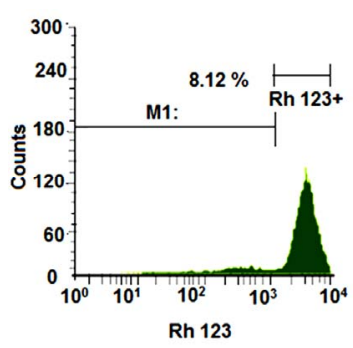

(a)

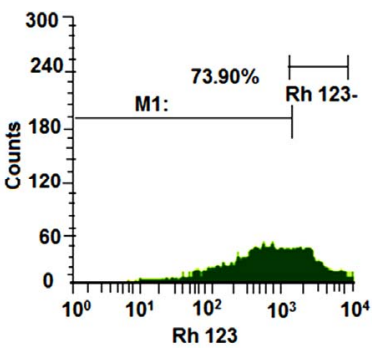

(b)

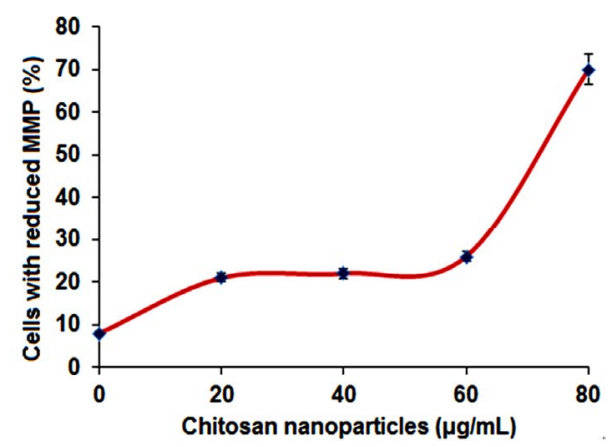

(c)

Figure 8. (a) Histogram of untreated cells; (b) Histogram of cells treated with $100 \mu \mathrm{g} / \mathrm{ml}$ chitosan nanoparticles; (c) Chitosan nanoparticles-induced changes of MMP (loss of MMP).

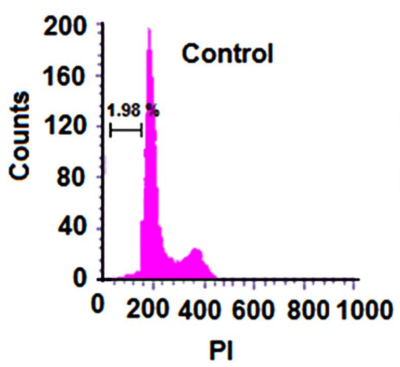

(a)

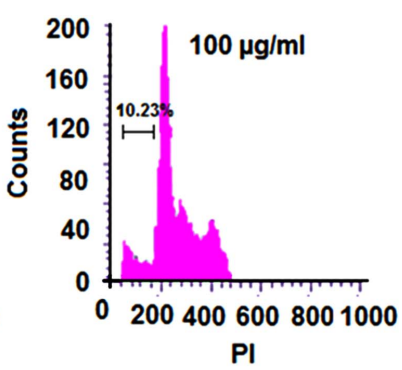

(b)
Figure 9. (a) Effect of chitosan nanoparticles on cell cycle of SUDHL-4 cells; (b) Apoptotic incidence of SUDHL-4 cells.

with TPP. The high loading competence with an efficient carrier was observed in the optimization ratio of chitosan to TPP (4:1). The present study demonstrated that a high cytotoxicity against human lymphoma SUDHL-4 cell line could exert in chitosan nanoparticles. It was proved that the cell line is susceptible to CH-NPs by an $\mathrm{IC}_{50}$ value of $5 \mu \mathrm{g} / \mathrm{ml}$ after $48 \mathrm{~h}$ action signifying that CHNPs are perhaps an excellent choice for antitumor drugs. Thus, size of the nanoparticles was mostly responsible in antitumor activity and in vivo distribution. Higher accumulation of tumour sites and makes longer half-life in vivo due to small size of nanoparticles. Here, the antitumor activity which prolongs efficiency could be controlled by using $78 \mathrm{~nm}$ particle size of CH-NPs. The CHNPs showed both lower as well as higher cationic charge densities which have higher cytotoxicity effects. The 
major factor for this cytotoxicity effect of chitosan derivatives is because of electrostatic ionic interface among the groups of negatively charged tumour cells and positively charged amino groups of chitosan. Therefore, the CH-NPs with $52 \mathrm{mV}$ surface charge are responsible to make it higher cytotoxicity activity. Furthermore, the CH-NPs inhibited effectively the proliferation of Lymphoma SUDHL-4 in vitro through multiple mechanisms. These novel findings strengthen our hypothesis and can open a new path for further research against human lymphoma.

\section{ACKNOWLEDGEMENTS}

Authors are thanks to CSIR, Govt. of India for providing financial support. Authors are also grateful to CIPET, Bhubaneswar and Chennai of India for their help in this research. Authors have no any conflicts of interest in this manuscript. No writing assistance was utilized for preparation of this manuscript.

\section{REFERENCES}

[1] Parida, U.K., Nayak, A.K., Bindhani, B.K. and Nayak, P.L. (2011) Synthesis and characterization of chitosan-polyvinyl alcohol blended with cloisite $30 \mathrm{~B}$ for controlled release of the anticancer drug curcumin. Journal of Biomaterials and Nanobiotechnology, 2, 414-425. http://dx.doi.org/10.4236/jbnb.2011.24051

[2] Qian, C., Xu, X., Shen, Y., Li, Y. and Guo, S. (2013) Synthesis and preliminary cellular evaluation of phosphonium chitosan derivatives as novel non viral vector. Carbohydrate Polymers, 97, 676-683.

[3] Shukla, S.K., Mishra, A.K., Arotiba, O.A. and Mamba, B.B. (2013) Chitosan-based nanomaterials: A state-ofthe-art review. International Journal of Biological Macromolecules, 59, 46-58.

[4] Di Martino, A., Sittinger, M. and Risbud, M.V. (2005) Chitosan: A versatile biopolymer for orthopaedic tissueengineering. Biomaterials, 26, 5983-5990. http://dx.doi.org/10.1016/j.biomaterials.2005.03.016

[5] Senel, S. and Mc Clure, S.J. (2004) Potential applications of chitosan in veterinary medicine. Advanced Drug Delivery Reviews, 56, 1467-1480. http://dx.doi.org/10.1016/j.addr.2004.02.007

[6] Khor, E. and Lim, L.Y. (2003) Implantable applications of chitin and chitosan. Biomaterials, 24, 2339-2349. http://dx.doi.org/10.1016/S0142-9612(03)00026-7

[7] Bumgardner, J.D., Wiser, R., Gerard, P.D., Bergin, P., Chestnutt, B., Marini, M., Ramsey, V., Elder, S.H. and Gilbert, J.A. (2003) Chitosan: Potential use as a bioactive coating for othopaedic and craniofacial/dental implants. Journal of Biomaterials Science, Polymer Edition, 14, 429-438. http://dx.doi.org/10.1163/156856203766652048

[8] Kumar, M.N.V.R. (2000) A review of chitin and chitosan applications. Reactive and Functional Polymers, 46, 127. http://dx.doi.org/10.1016/S1381-5148(00)00038-9

[9] Synowiecki, J. and Khateeb, N.A. (2003) Production, properties and some new applications of chitin and its derivatives. Critical Reviews in Food Science and Nutrition, 43, 145-171. http://dx.doi.org/10.1080/10408690390826473

[10] Shon, D.H. (2001) Chitosan oligosaccharides for functional foods and microbial enrichment of chitosan oligosaccharides in soy-paste. Proceedings of the International Workshop on Bioactive Natural Products, Tokyo, 56-66.

[11] Tharanathan, R.N. and Kittur, F.S. (2003) Chitin-The undisputed biomolecule of great potential, Critical Reviews in Food Science and Nutrition, 43, 61-87. http://dx.doi.org/10.1080/10408690390826455

[12] Sekiguchi, S., Miura,Y., Kancko, H., Nishimura, S.L., Nishi, N., Iwase, M. and Tokura, S. (1994) Molecular weight dependency of antimicrobial activity by chitosan oligomers. In: Nishimuri E. and Doi, E., Eds., Food Hydrocolloids: Structure, Properties and Function, Plenum Press, New York, 71-76.

[13] Jeon, Y.J., Park, P.J. and Kim, S.K. (2001) Antimicrobial effect of chitooligosaccharides produced by bioreactor. Carbohydrate Polymers, 44, 71-76. http://dx.doi.org/10.1016/S0144-8617(00)00200-9

[14] Kondo, Y., Nakatani, A., Hayashi, K. and Ito, M. (2000) Low molecular weight chitosan prevents the progression of low dose streptozotocin induced slowly progressive diabetes mellitus in mice. Biological \& Pharmaceutical Bulletin, 23, 1458-1464. http://dx.doi.org/10.1248/bpb.23.1458

[15] Tsai, G.J., Wu, Z.Y. and Su, W.H. (2000) Antibacterial activity of a chitooligosaccharide mixture prepared by cellulase digestion of shrimp chitosan and its application in milk preservation. Journal of Food Protection, 63, 747-752.

[16] Tsai, G.J., Wu, Z.Y. and Su, W.H. (2000) Antibacterial activity of a chitooligosaccharide mixture prepared by cellulase digestion of shrimp chitosan and its application in milk preservation. Journal of Food Protection, 63, 747-752.

[17] Richardson, S.C.W., Kolbe, H.V.J. and Duncan, R. (1999) Potentials of low molecular mass chitosan as a DNA delivery system: Biocompatibility, body distribution and ability to complex and protect DNA. International Journal of Pharmaceutics, 178, 231-243.

[18] Vimal, S., Abdul Majeed, S., Taju, G., Nambi, K.S., Sundar Raj, N., Madan, N., Farook, M.A., Rajkumar, T., Gopinath, D. and Sahul Hameed, A.S. (2013) Chitosan tripolyphosphate (CS/TPP) nanoparticles: Preparation, characterization and application for gene delivery in shrimp. Acta Tropica, 128, 486-493.

[19] Oliveira, A.V., Silva, A.P., Bitoque, D.B., Silva, G.A. and Rosa da Costa, A.M. (2013) Transfection efficiency of chitosan and thiolated chitosan in retinal pigment epithelium cells: A comparative study. Journal of Pharmacy and Bioallied Sciences, 5, 111-118.

[20] Qi, L.F., Xu, Z.R., Li, Y., Jiang, X. and Han, X.Y. (2005) In vitro effects of chitosan nanoparticles on proliferation of human gastric carcinoma cell line MGC803 cells. World Journal of Gastroenterology, 11, 5136-5141.

[21] Singh, D.J., Lohade, A.A., Parmar, J.J., Hegde, D.D., 
Soni, P., Samad, A. and Menon, M.D. (2012) Development of Chitosan-based Dry Powder inhalation System of Cisplatin for Lung Cancer. Indian Journal of Pharmaceutical Sciences, 74, 521-526.

[22] Del Turco, S., Ciofani, G., Cappello. V., Gemmi, M., Cervelli, T., Saponaro, C., Nitti, S., Mazzolai, B., Basta, G. and Mattoli, V. (2013) Cytocompatibility evaluation of glycol-chitosan coated boron nitride nanotubes in human endothelial cells. Colloids Surf B: Biointerfaces, 111C, 142-149. http://dx.doi.org/10.1016/j.colsurfb.2013.05.031

[23] Paiva, D., Ivanova, G., do Carmo Pereira, M. and Rocha, S. (2013) Chitosan conjugates for DNA delivery. Physical Chemistry Chemical Physics, 15, 11893-11899.

[24] Liang, X., Li, X., Chang, J., Duan, Y. and Li, Z. (2013) Properties and evaluation of quaternized chitosan/lipid cation polymeric liposomes for cancer-targeted gene delivery. Langmuir, 29, 8683-8693. http://dx.doi.org/10.1021/la401166v

[25] Sahu, A., Goswami, P. and Bora U. (2009) Microwave mediated rapid synthesis of chitosan. Journal of Materials Science: Materials in Medicine, 20, 171-175. http://dx.doi.org/10.1021/la401166v

[26] Cheng, C.Y. and Li, Y.K. (2000) An Aspergillus chitinase with potential for largescale preparation of chitosan oligosaccharides, Biotechnol. Biotechnology and Applied Biochemistry, 32, 197-203. http://dx.doi.org/10.1042/BA20000063

[27] Baxter, A., Dillon, M. and Anthony Taylor, K.D. (1992) Improved method for i.r. determination of the degree of $\mathrm{N}$-acetylation of chitosan. International Journal of Biological Macromolecules, 14, 66-69.

[28] Lavertu, M., Xia, Z., Serrequ, A.N., Berrada, M., Rodrigues, A., Wang, D., Buschmann, M.D. and Gupta, A. (2003) A validated 1H-NMR method for the determination of the degree of deacetylation of chitosan. Journal of Pharmaceutical and Biomedical Analysis, 32, 1149-1158.

[29] Venkatesan, P., Puvvada, N., Dash, R., Prashanth Kumar, B.N., Sarkar, D., Azab, B., Pathak, A., Kundu, S.C., Fisher, P.B. and Mandal, M. (2011) The potential of celecoxib-loaded hydroxyapatite-chitosan nanocomposite for the treatment of colon cancer. Biomaterials, 32, 37943806. http://dx.doi.org/10.1016/j.biomaterials.2011.01.027

[30] Huang, Y. and Lapitsky, Y. (2011) Monovalent salt enhances colloidal stability during the formation of chotosan/tripolyphosphate microgels. Langmuir, 27, 1039210399.

[31] Jeevitha, D. and Amarnath, K. (2013) Chitosan/PLA nanoparticles as a novel carrier for the delivery of anthraquinone: Synthesis, characterization and in vitro cytotoxicity evaluation. Colloids Surfaces B: Biointerfaces, 101, 126-134.

[32] Kim, H., You, S., Kong, B.W., Foster, L.K., Farris, J. and Foster, D.N. (2001) Necrotic cell death by hydrogen peroxide in immortal DF-1 chicken embryo fibroblast cells expressing deregulated MnSOD and catalase. Biochimica et Biophysica Acta, 1540, 137-146. http://dx.doi.org/10.1016/S0167-4889(01)00131-8
[33] Behl, G., Sharma, M., Dahiya, S., Chhikara, A. and Chopra, M. (2011) Synthesis, characterization, and evaluation of radical scavenging ability of ellagic acid-loaded nanogels. Journal of Nanomaterials, 1-9. http://dx.doi.org/10.1155/2011/695138

[34] Zhang, Z.P. and Feng, S.-S. (2006) The drug encapsulation efficiency, in vitro drug release, cellular uptake and cytotoxicity of paclitaxel-loaded poly (lactide)-tocopheryl polyethylene glycol succinate nanoparticles. Biomaterials, 27, 4025-4033. http://dx.doi.org/10.1016/j.biomaterials.2006.03.006

[35] Stacey, N.B., Samantha, M.Y., Karl, R.F., Areti, T., Omid, K. and Ipsita, A.B. (2011) Ellagic acid promoted biomimetic synthesis of shape-controlled silver nanochains. Nanotechnology, 22, 1-10. http://dx.doi.org/10.1088/0957-4484/22/22/225605

[36] Sonaje, K., Italia, J.L., Sharma, G., Bhardwaj, V., Tikoo, K. and Ravi Kumar, M.N.V. (2007) Development of biodegradable nanoparticles for oral delivery of ellagic acid and evaluation of their antioxidant efficacy against cyclosporine A-induced nephrotoxicity in rats. Pharmaceutical Research, 24, 899-908. http://dx.doi.org/10.1007/s11095-006-9207-y.

[37] Gautam, B., Monal, S., Saurabh, D., Aruna, C. and Madhu, C. (2011) Synthesis, characterization, and evaluation of radical scavenging ability of ellagic acid-loaded nanogels. Journal of Nanomaterials, 2011, Article ID: 695138. http://dx.doi.org/10.1155/2011/695138

[38] Mostafa, A.D., Adel Zaki, E., Mohamed, M.A. and Dina, M.D.B. (2012) Thermal stability and degradation of chitosan modified by cinnamic acid. Open Journal of Polymer Chemistry, 2, 14-20. http://dx.doi.org/10.4236/ojpchem.2012.21003

[39] Zobir, M.H., Samer, H.A.A., Zulkarnain, Z. and Muhammad, N.H. (2011) Development of antiproliferative nanohybrid compound with controlled release property using ellagic acid as the active agent. International Journal of Nanomedicine, 6, 1373-1383.

[40] Yokoyama, M., Satoh, A., Sakurai, Y., Okano, T., Matsumura, Y., Kakizoe, T. and Kataoka, K. (1998) Incorporation of water-insoluble anticancer drug into polymeric micelles and control of their particle size. Journal of Controlled Release, 55, 219-229.

[41] Zhang, L.Y., Hu, Y., Jiang, X.Q., Yang, C.Z., Lu, W. and Yang, Y.H. (2004) Camptothecin derivative-loaded poly (caprolactone-co-lactide)-b-PEG-b-poly(caprolactone-colactide) nanoparticles and their biodistribution in mice. Journal of Controlled Release, 96, 135-148. http://dx.doi.org/10.1016/i.jconrel.2004.01.010

[42] Jinno, H., Ikeda, T., Matsui, A., Kitagawa, Y., Kitajima, M., Fujii, H., Nakamura, K. and Kubo, A. (2002) Section 5. Breast Sentinel lymph node biopsy in breast cancer using technetium-99m tin colloids of different sizes. Biomedicine and Pharmacotherapy, 56, 213-216.

[43] Takenaga, M. (1996) Application of lipid microspheres for the treatment of cancer. Advanced Drug Delivery Reviews, 20, 209-219.

[44] Yuan, X., Yang, X., Cai, D., Mao, D., Wu, J., Zong, L. and Liu, J. (2008) Intranasal immunization with chito- 
san/pCETP nanoparticles inhibits atherosclerosis in a rabbit model of atherosclerosis. Vaccine, 26, 3727-3734. http://dx.doi.org/10.1016/j.vaccine.2008.04.065

[45] Morrison, M.R. and Smith, M. (1963) Preparation of fatty acid methyl esters and dimethyl acetyls from lipids with boron fluoride methanol. Journal of Lipid Research, 5, 600608.

[46] Focher, B., Naggi, A., Torri, G., Cosani, A. and Terbojevich, M. (1992) Chitosans from Euphausia superba. 2: Characterization of solid-state structure. Carbohydrate Polymers, 18, 43-49.

[47] Monti, M.G., Ghiaroni, S., Marverti, G., Montanari, M. and Moruzzi, M.S. (2004) Polyamine depletion switches the form of 2-deoxy-d-ribose induced cell death from apoptosis to necrosis in HL-60 cells. The International Journal of Biochemistry \& Cell Biology, 36, 1238-1248.

[48] Vishu Kumar, A.B., Varadaraj, M.C., Lalitha, R.G. and
Tharanathan, R.N. (2005) Characterization of chito-oligosaccharides prepared by chitosanolysis with the aid of papain and pronase, and their bactericidal action against $\mathrm{Ba}$ cillus cereus and Escherichia coli. Biochemical Journal, 391, 167-175.

http://dx.doi.org/10.1042/BJ20050093

[49] Kanjanathaworn, N., Polpanich, D., Jangpatarapongsa, K. and Tangboriboonrat, P. (2013) Reduction of cytotoxicity of natural rubber latex film by coating with PMMA-chitosan nanoparticles. Carbohydrate Polymers, 97, 52-58. http://dx.doi.org/10.1016/j.carbpol.2012.12.078

[50] Yang, S.J., Chang, S.M., Tsai, K.C., Tsai, H.M., Chen, W.S. and Shieh, M.J. (2012) Enhancement of chitosan nanoparticle-facilitated gene transfection by ultrasound both in Vitro and in Vivo. Journal of Biomedical Materials Research. Part B, Applied Biomaterials, 100, 1746-1754. http://dx.doi.org/10.1002/jbm.b.32741 